\title{
Survival of Lactobacillus plantarumU40 on the in vitro rumen fer- mentation quantified with real-time PCR
}

\author{
W.D. Astuti ${ }^{1,2}$, Y. Widyastuti ${ }^{2}$, E. Wina ${ }^{3}$, S. Suharti ${ }^{4}$, R. Ridwan ${ }^{2}$ and K.G. Wiryawan ${ }^{4, *}$ \\ ${ }^{1}$ Graduate School of Animal Nutrition and Feed Science, \\ Bogor Agricultural University, Jl. Agastis, Darmaga Campus, Bogor 16680 - Indonesia \\ ${ }^{2}$ Research Center for Biotechnology, Indonesian Institute of Sciences, \\ Jl. Raya Bogor-Jakarta Km. 46, Cibinong, West Java 16911 - Indonesia \\ 3 Indonesian Research Institute for Animal Production, \\ Jl. Veteran III, Banjarwaru PO Box 221, Bogor 16002 - Indonesia \\ ${ }^{4}$ Department of Animal Nutrition and Feed Technology, Faculty of Animal Science, \\ Bogor Agricultural University, Jl.Agastis, Darmaga Campus , Bogor 16680 - Indonesia \\ *Corresponding E-mail: kgwiryawan61@gmail.com
}

Received April 22, 2018; Accepted May 19, 2018

\begin{abstract}
ABSTRAK
Tujuan dari penelitian ini adalah untuk menganalisa daya tahan L. plantarumU40 menggunakan real-time PCR dalam fermentasi rumen in vitro. Desain penelitian yang digunakan adalah Rancangan Acak Kelompok dengan 3 perlakuan dan 4 ulangan. Perlakuan yang diberikan adalah kontrol, inokulasi dengan L. plantarum $\mathrm{U} 40$ danL. plantarum $\mathrm{U} 40+$ glukosa. Perlakuan dengan inokulasi menghasilkan populasi $L$. plantarum $\mathrm{U} 40$ yang lebih tinggi. Setelah 8 jam inkubasi, pemberian glukosa cenderung menurunkan populasi L. plantarum U40. Perlakuan kontrol menghasilkan populasi L. plantarum U40 yang paling rendah selama fermentasi in vitro.Inokulasi $L$. plantarum U40meningkatkan populasi Bakteri Asam Laktat secara signifikan $(\mathrm{P}<0.05)$ sampai dengan 12 jam inkubasi dibandingkan dengan kontrol. Perlakuan kontrol mempunyai $\mathrm{pH}$ yang paling tinggi selama masa inkubasi. Penambahan glukosa secara signifikan $(\mathrm{P}<0.05)$ menurunkan $\mathrm{pH}$ rumen pada akhir inkubasi (24 jam) (6.30), dibandinkgkan dengan kontrol (6.85).Inokulasi dengan $L$. plantarum $\mathrm{U} 40+$ glukosa secara signifikan $(\mathrm{P}<0.05)$ meningkatkan asam propionat, menurunkan asam asetat serta nisbah $\mathrm{A} / \mathrm{P}$ dibanding perlakuan lainnya.Lactobacillus plantarum U40 tanpa penambahan glukosa tidak memberikan efek terhadap produksi propionat secara signifikan. Dapat disimpulkan bahwa Lactobacillus plantarumU40 dapat bertahan hidup di dalam rumen serta mengubah fermentasi rumen ketika glukosa ditambahkan sebagai sumber karbon.
\end{abstract}

Kata kunci: Lactobacillus plantarumU40, daya tahan, glukosa,fermentasi rumen, quantitative real-time PCR

\begin{abstract}
The objective of this study was to evaluate the survival of $L$. plantarum $\mathrm{U} 40$ quantified with realtime PCR during in vitro rumen fermentation. The experiment was arranged in a randomized block design with 3 treatments and 4 replications. Treatments were control, rumen fermentation inoculated with L. plantarum U40and L. plantarumU40 + glucose solution. Population of L. plantarum U40 was higher at inoculation treatment. After 8 hours incubation, glucose addition tended to decrease $L$. plantarum U40 population. Control treatment showed lowest population of L. plantarum U40 along in
\end{abstract}


vitro fermentation compared with other treatment. Inoculation of $L$. plantarum $\mathrm{U} 40$ significantly $(\mathrm{p}<0.05)$ increased population of LAB until 12 hours incubation compared with control. Control treatment had highest $\mathrm{pH}$ at all incubation time. Glucose addition significantly $(\mathrm{P}<0.05)$ decreased final rumen $\mathrm{pH}$ (24 hours) (6.30), compared with control treatment (6.85). Inoculation of L. plantarum U40 with glucose addition significantly $(\mathrm{P}<0.05)$ increased propionic acid, decreased acetic acid and $\mathrm{A} / \mathrm{P}$ ratio compared with other treatments. Lactobacillus plantarum U40 without glucose addition did not affect propionic acid production significantly. As conclusion, Lactobacillus plantarum U40 can survive in rumen fluid and changes rumen fermentation when glucose is added as carbon source.

Keywords: Lactobacillus plantarumU40, survival, glucose, rumen fermentation, quantitative realtime PCR

\section{INTRODUCTION}

Demand of probiotic in animal production is increasing due the total ban of antibiotic application as feed additives started from 2006 onwards in European Union countries (Cheng et al., 2014; Yirga, 2015) and 2018 in Indonesia according to The Regulation of Minister of Agriculture number 14/Permentan/PK. 350/5/2017.According to FAO/WHO (2001) probiotics defined as living microbes which when administered in adequate amounts confer a health benefit to the host. The working of probiotics in the rumen would yield benefits such as modified fermentation patterns and enhanced fiber digestion, both of which are directly linked to improve animal performance (McAllister et al. 2011).

The probiotic effect of lactic acid bacteria (LAB) has been documented in human and animals. Species of Lactobacillus, Bifidobacterium, Enterococcus, Streptococcus, Bacillus and Propionibacterium are LAB that already used as probiotics for ruminants (Seo et al., 2010). Lactobacillus species stimulate indigenous $\mathrm{LAB}$ and the production of short-chain fatty acids, and may modulate the intestinal immune response (Ohashi and Ushida, 2009). Several LAB species including Lactobacillus plantarum, Lactobacillus acidophilus and Enterococcus faecium were evaluated as potential probiotics, as they stimulate the activity of lactic acid utilizing rumen microbes and thereby ameliorate and prevent acidosis (McAllister et al. 2011).

In order to affect rumen microbes as beneficial effects of probiotic, the survival of LAB in the rumen needs to be addressed. Weinberg et al. (2003) examined the changes in populations of silage LAB ( $L$. plantarum, $E$. faecium and Pediococcus pentosaceus) during in vitro rumen incubation and concluded that acceptable numbers of LAB could survive, particularly when sugar substrates were fortified. Similarly, Rodriguez-Palacios et al. (2009) isolated $L$. plantarum from caecum content and both $P$. pentosaceus and $P$. acidilactici from bovine faecal matter, suggesting that LAB species used as inoculants may survive and confer probiosis in both the rumen and intestine.

One hypothesis about the mechanism of $L$. plantarum as probiotic is its interaction with rumen microbes to enhance rumen functionality (Weinberg et al., 2004). Only limited studies have been reported about the survival of $L$. plantarum in rumen fluid, mostly because its' role as probiotic for ruminant is not clear yet. For that reason, the survival of the strain during rumen fermentation as one of a desirable probiotic property for ruminant (FAO/WHO, 2002), need to be examined. Real-time PCR has the ability to enumerate species specific targeted bacteria with high sensitivity and has been used to analyze rumen microbes samples (Wanapat and Cherdthong, 2009; Singh et al., 2014; Grilli et al., 2016). Therefore, the objective of this study was to evaluate the survival of $L$. plantarum $\mathrm{U} 40$ quantified with real-time PCR during in vitro rumen fermentation.

\section{MATERIALS AND METHODS}

The study was conducted at the Research Center for Biotechnology, Indonesian Institute of Sciences (LIPI), Cibinong, West Java, Indonesia.

\section{Lactobacillus plantarum Strain and Culture Conditions}

Strain L. plantarum $\mathrm{U} 40$ used in this study was collection of Laboratory of Applied Microbiology, Research Center for Biotechnology, Indonesian Institute of Sciences (LIPI). It was isolated from rumen of Ongole Breed cattle (Ridwan et al., 2018). It was cultured 
in deMan Rogosa Sharpe (MRS) broth medium (Merck, Darmstadt, Germany) (Weinberg et al., 2003; Jiao et al., 2017) at $39^{\circ} \mathrm{C}$ under anaerobic conditions.

\section{In vitro Rumen Fermentation and Experimental Design}

Rumen fluid was obtained from two rumenfistulated Ongole crossbred cattle before morning feeding, mixed in equal portion. The rumenfistulated Ongole crossbred cattle were managed according to the protocols approved by the Ethic Clearance Committee of Indonesian Institute of Sciences (Number 9879/WK/HK/XI/2015). Rumen fluid was filtered through a double layer of cheesecloth for in vitro studies, pooled in prewarmed bottles, sealed and immediately transported to the laboratory.

The experiment design was arranged in a randomized block design with 3 treatments and 4 replications. The experiment was repeated 4 different times which treated as block. Rumen fermentation without any addition served as a control (C). Two other treatments were inoculation of L. plantarum U40 (RP) and inoculation of $L$. plantarum $\mathrm{U} 40+$ glucose solution (RPG). Rumen fluid for RPG treatments was added with sterile $50 \%(\mathrm{w} / \mathrm{v})$ glucose solution to a final concentration of $5 \mathrm{~g} / \mathrm{L}$ according to Weinberg et al. (2003). One $\mathrm{ml}$ of $L$. plantarum $\mathrm{U} 40$ strain $\left(10^{9} \mathrm{cfu} / \mathrm{mL}\right)$ was inoculated to each experimental bottle with RP and RPG treatments.

In vitro rumen fermentation was conducted using serum bottle glass, filled with $75 \mathrm{ml}$ mixture rumen fluid and Mc'Dougall buffer (1:2 ratio). The bottle was closed with rubber cap and aluminum crimp after flushed with $\mathrm{CO}_{2}$ gas for 30 $\mathrm{s}$ to get anaerobic conditions and incubated in water bath incubator at temperature of $39^{\circ} \mathrm{C}$ (Theodorou, 1994). At 0, 4, 8, 12 and $24 \mathrm{~h}$ incubation, bottles from each treatment were sampled for $\mathrm{pH}$, and LAB population measurement.VFA concentration and NH3 were measured from rumen fluid at $8 \mathrm{~h}$ incubation. Some rumen fluid from each treatment at $0,4,8$, 12 and $24 \mathrm{~h}$ incubations were kept in $-20^{\circ} \mathrm{C}$ for further analysis.

Rumen $\mathrm{pH}$ was measured with $\mathrm{pH}$ meter (Cyberscan 310, Eutech Instruments, Singapore). Concentration of $\mathrm{NH}_{3}$ was measured by the microdiffusion Conway method (General Laboratory Procedures, 1966). Total VFA concentration and molar proportions of VFA were analyzed by using gas chromatography (GC 8A, Shimadzu Corp., Kyoto, Japan with capillary coloumn type containing 10\% SP-1200, 1\% H3PO4 on 80/100 Cromosorb WAW and nitrogen as gas carrier). LAB population was quantified with Total Plate Count (TPC) method using MRS agar plate in the form of colony-forming units (cfu) (Cappucino and Sherman, 2001), incubated at $39^{\circ} \mathrm{C}$ for 24 hours in anaerobic condition using anaerobic jar with anaeropack (AnaeroGen ${ }^{\mathrm{TM}}$, Thermo Scientific, Japan) to reduce the oxygen.

\section{DNA Extraction}

Genomic DNA was extracted from $0.5 \mathrm{~mL}$ aliquots of rumen fluid from in vitro fermentation using Geneaid ${ }^{\mathrm{TM}}$ DNA isolation kit (Geneaid Biotech Ltd., Taiwan), following manufacturer's recommendation. Some modifications were applied according to Ridwan et al. (2015). The DNA quality and quantity were checked by agarose gel electrophoresis and NanoDrop spectrophotometer (P-330, Implen NanoPhotometer, Germany) by the absorbance at $260 \mathrm{~nm}$.

\section{Real-Time PCR}

All quantification of Real-time PCR amplification and detection were performed using Bio-Rad CFX 96 Touch $^{\mathrm{TM}}$ Real time PCR Detection System.Species-specific PCR primers for $L$. plantarum used to amplify partial $16 \mathrm{~S}$ rDNA regions (target DNA) were F:3'TTACATTTGAGTGAGTGGCGAACT-5, for forward primer and R:3'AGGTGTTATCC CCCGCTTCT-5' for reversed primer (Klocke et al., 2006). The reaction was conducted inafinal volume of $20 \mu \mathrm{L}$, carried out in duplicate, containing the following: $10 \mu \mathrm{L}$ SsoFast SYBR Green Real-Time PCR master mix (product of BioRad), $0.4 \mu \mathrm{L}$ forward primer, $0.4 \mu \mathrm{L}$ reverse primer, 7.2 $\mu \mathrm{L}$ Nucleus-Free Water (NFW), and 2 $\mu \mathrm{L}$ DNA template. Amplification programme included an initial denaturation step at $95^{\circ} \mathrm{C}$ for 5 min followed by 30 cycles of denaturation at $95^{\circ} \mathrm{C}$ for $10 \mathrm{~s}$, annealing at $50^{\circ} \mathrm{C}$ for $30 \mathrm{~s}$ and extension at $95^{\circ} \mathrm{C}$ for $30 \mathrm{~s}$. Negative control without DNA template were run with every assay to assess the overall specificity. All PCR were performed in duplicate. Absolute quantification involved the use of standard curves for L. plantarumU40. The construction of standard curves using 10-fold serial dilutions in NFW prior to real-time PCR. 


\section{Statistical Analysis}

Data were analysed by one way analysis of variance using SPSS 16 (SPSS, Inc., IBM, Chicago). Significant effects of treatments were determined by Duncan's multiple range test method. Significant differences were accepted if $\mathrm{P}<0.05$.

\section{RESULTS AND DISCUSSIONS}

The isolate $L$. plantarum $\mathrm{U} 40$ used in this experiment was selected as best candidates as probiotic for ruminants as the result of previous study (Astuti et al., 2018). Investigating the survival of this strain in rumen fluid is important to strengthen its potency as probiotic for ruminant. Figure 1 shows the population of $L$. plantarum $\mathrm{U} 40$ in rumen fluid during 24 hours in vitro fermentation, as quantified by the real-time PCR assays. Although it was not significant, control treatment without inoculation tended to had the lowest population of L. plantarum $\mathrm{U} 40$ along in vitro fermentation, indicating that $L$. plantarum $\mathrm{U} 40$ in the control treatment originated only from rumen fluid. In early stage of fermentation (0-8 hours), population of $L$. plantarum U40 with or without glucose addition were equal. After $8 \mathrm{~h}, L$. plantarum U40 population tended to decrease when glucose was added as carbon source, and it continued until the end of incubation. Although it was not significant, decreased of L. plantarum $\mathrm{U} 40$ in the present of glucose was surprising, considering glucose addition was expected to serve as carbon source for L. plantarum U40 to ensure their survival in the rumen fluid. After $8 \mathrm{~h}$, glucose in the rumen fluid was totally used by rumen microbes. Decreased of $L$. plantarum U40 population possibly was an adaptation reaction for lacked of glucose which usually consumed in this treatment. Inoculation of $L$. plantarum U40 without glucose also decreased $L$. plantarum $\mathrm{U} 40$ population after $8 \mathrm{~h}$, but not as much as treatment with glucose.

Inoculation of $L$. plantarum $\mathrm{U} 40$ affected population of LAB in the rumen fluid for $12 \mathrm{~h}$ incubation on in vitro fermentation (Table 1). At 0 $\mathrm{h}$ incubation, LAB population from rumen with inoculation $L$. plantarum $\mathrm{U} 40$ treatment was higher than control, because of L. plantarum $\mathrm{U} 40$ added to those treatments was living culture and increased LAB population. After that $(4 \mathrm{~h})$, population of $\mathrm{LAB}$ in the rumen fluid with inoculation $L$. plantarum $\mathrm{U} 40$ treatment was decreased, showing adaptation period needed by $L$. plantarum $\mathrm{U} 40$ to survive in the rumen fermentation environment. During adaptation period, glucose addition provides $L$. plantarum $\mathrm{U} 40$ and other LABs a substrate to help them survived. As a result, decrease LAB population during adaptation period in glucose addition treatment was not as much as in treatment without glucose. The highest population of $\mathrm{LAB}$ at $4 \mathrm{~h}$ incubation was resulted from glucose addition treatment (7.85), significantly

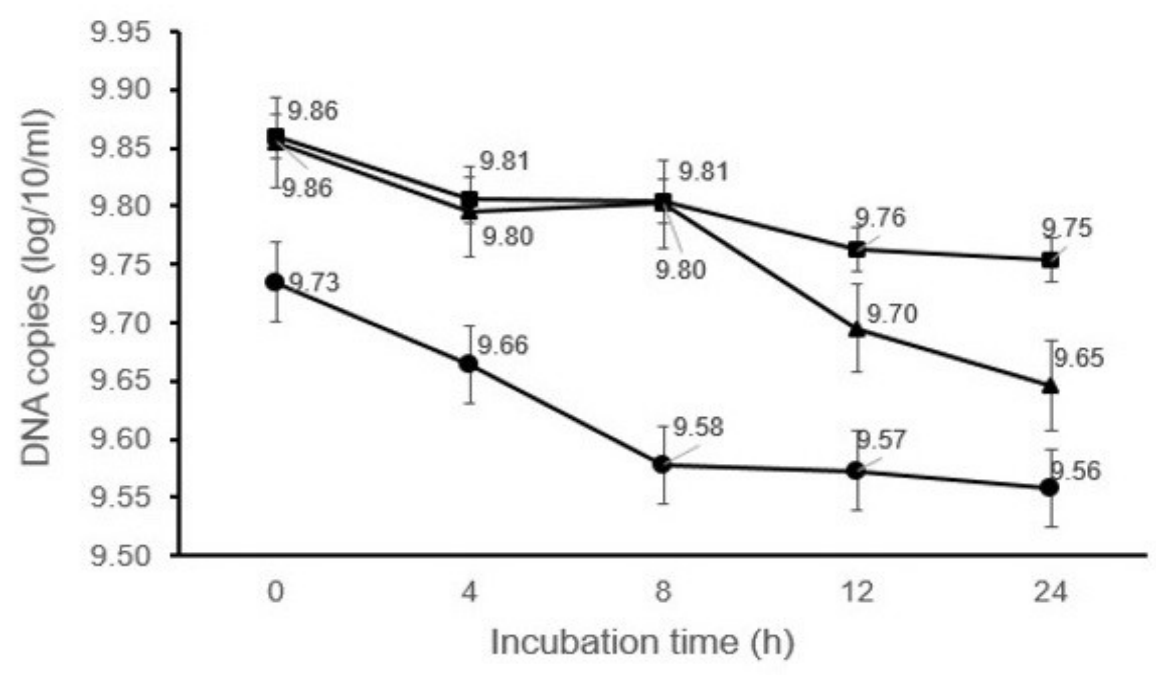

Figure 1. Population of L. plantarum in Rumen Fluid during 24 Hours in vitro Fermentation. The Symbols Represent Control $(\bullet)$, L. plantarum $(\boldsymbol{\square})$ and L. plantarum + glucose $(\boldsymbol{\Delta})$. Data Points are Mean Values based on Four Replicates. Error Bars represent standard deviation of the Mean. 
Table 1. Effect of L. plantarum U40 on LAB Population $(\log 10 \mathrm{cfu} / \mathrm{mL})$ during In vitro Fermentation

\begin{tabular}{lccccc}
\hline \multirow{2}{*}{ Treatments } & \multicolumn{5}{c}{ Incubation time (h) } \\
\cline { 2 - 6 } & 0 & 4 & 8 & 12 & 24 \\
\hline Control & $6.48^{\mathrm{a}}$ & $6.45 \mathrm{a}$ & $6.64^{\mathrm{a}}$ & $6.13^{\mathrm{a}}$ & 5.72 \\
L. plantarum $\mathrm{U} 40$ & $8.36^{\mathrm{b}}$ & $7.16 \mathrm{~b}$ & $8.04^{\mathrm{b}}$ & $7.97^{\mathrm{b}}$ & 6.73 \\
L. plantarum $\mathrm{U} 40+$ glucose & $8.28^{\mathrm{b}}$ & $7.85 \mathrm{c}$ & $7.73^{\mathrm{b}}$ & $7.66^{\mathrm{b}}$ & 6.07 \\
\hline
\end{tabular}

Different superscripts within the same column indicate significantly different at $\mathrm{P}<0.05$

higher than control (6.45) and L. plantarum U40 without glucose addition (7.16).

At 8 and $12 \mathrm{~h}$ incubation, there was no significant different of LAB population between inoculation of $L$. plantarum U40 with or without glucose addition. Glucose addition in this experiment was only significant during adaptation period to reduce the decreased of LAB population. After that, with or without glucose, LAB population was equal. Both treatments have significantly higher LAB population than control, showing that inoculated $L$. plantarum $\mathrm{U} 40$ was survive in rumen. After $24 \mathrm{~h}$ incubation, there was no significant different of LAB population between all treatments, although control still tended to have the lowest LAB population. It can be concluded that Lactobacillus plantarum U40 could affect LAB population in rumen ecosystem only for $12 \mathrm{~h}$. Ellis et al. (2016) also reported that effects of LAB inoculants may appear at initial stages on in vitro fermentation, and largely absent at the end of the incubation. Anaerobic condition of rumen was not the most suitable condition for facultative-anerobic bacteria such as Lactobacillus plantarum U40 (Smetanková, et al., 2012), although it's varies between strains.

\section{Lactobacillus plantarum $\mathrm{U} 40$}

was homogenous lactic acid bacteria. It produces lactic acid as their metabolism product. Lactic acid in rumen fermentation could decreased $\mathrm{pH}$ of rumen fluid. Changes of rumen $\mathrm{pH}$ during in vitro fermentation was observed at $0,4,8,12$ and 24 hours incubation (Figure 2). Control treatment had the highest $\mathrm{pH}$ at all incubation times. At $0 \mathrm{~h}$, inoculation of $L$. plantarum $\mathrm{U} 40$, either with or without glucose addition had significantly $(\mathrm{P}<0.05)$ lower $\mathrm{pH}$ than control. After that, glucose addition gave significant differences on rumen $\mathrm{pH}$. Inoculation of $L$. plantarum U40 without glucose addition resulted similar pattern of rumen $\mathrm{pH}$ with control treatment. While rumen
$\mathrm{pH}$ with glucose addition continue decreased until $24 \mathrm{~h}$ incubation, significantly $(\mathrm{P}<0.05)$ lower than other treatments. It confirmed that lower $\mathrm{pH}$ in treatment with glucose addition caused by lactic acid produced by $L$. plantarum U40. In this experiment, there was no other source of acid, other than lactic acid produced from LAB, that could decrease rumen $\mathrm{pH}$. This result was an evident that L. plantarum $\mathrm{U} 40$ can survive in the rumen fluid as long as there was enough supply of substrates to growth. Decreased of rumen $\mathrm{pH}$ after inoculation of LAB also reported by Ellis et al. (2016). Although inoculation of L. plantarum U40 caused rumen $\mathrm{pH}$ decreased, but it is still in the normal range which is suitable for growth and activity of rumen microbes. Krause and Oetzel (2006) mention that a physiological range of ruminal $\mathrm{pH}$ is between $5.5-7.0$.

Proposed mechanism for $L$. plantarum as ruminant probiotic was affects rumen microbes leading to changes on rumen fermentation products. Effects of L. plantarum $\mathrm{U} 40$ inoculation on in vitro rumen fermentation was shown in Table 2. Final $\mathrm{pH}$ of rumen fluid after 24 hours in vitro fermentation was significantly $(\mathrm{P}<0.05)$ lowered by glucose addition (6.30), compared with control treatment (6.85). Without glucose addition, inoculation of $L$. plantarum $\mathrm{U} 40$ did not change rumen final $\mathrm{pH}$. Decreased of rumen final $\mathrm{pH}$ could be resulted from lactic acid produced by L. plantarum U40. It seems that glucose addition provides substrate for L. plantarum U40 so they could survive and produced more lactic acid than without glucose addition.

Total VFA was not affected by inoculation of L. plantarum $\mathrm{U} 40$, although glucose addition tended to decrease VFA production. Glucose addition resulted in different effects of $L$. plantarum U40 on composition of VFA. Glucose addition decreased acetic acid production $(41.40 \%)$, significantly lower $(\mathrm{P}<0.05)$ than 


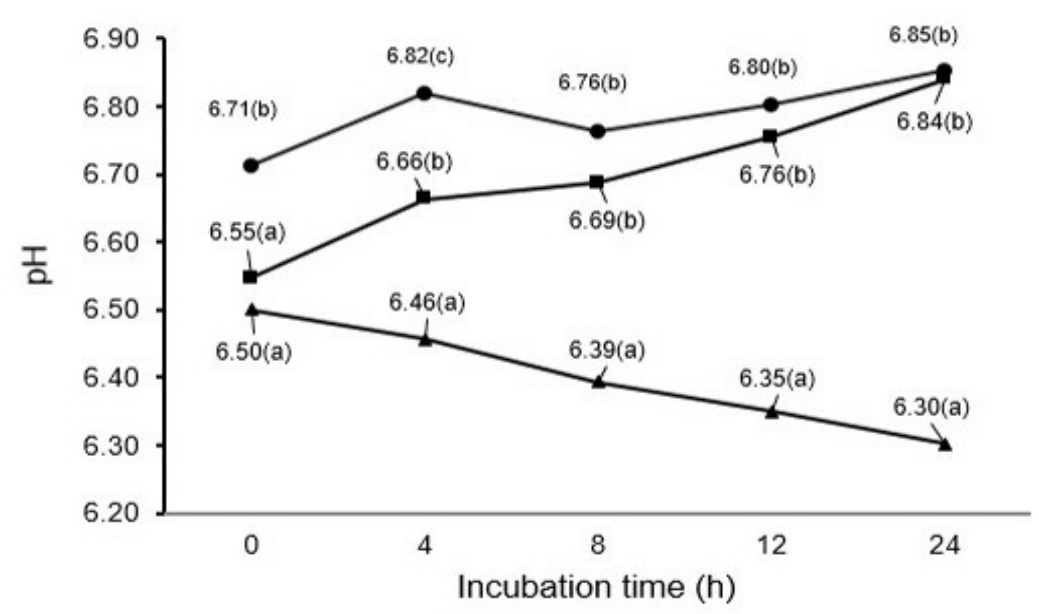

Figure 2. Effect of L. plantarum $\mathrm{U} 40$ on $\mathrm{pH}$ of Rumen Fluid during In vitro Fermentation. The Symbols Represent Control $(\bullet)$, L. plantarum (ם) and L. plantarum + glucose $(\mathbf{\Delta})$. Data Points are Mean Values based on Four Replicates. Error Bars Represent Standard Deviation of the Mean. Different Superscripts within the Same Incubation time $(0,4,8,12,24 \mathrm{~h})$ Indicate Significantly Different at $\mathrm{P}<0.05$ between Treatments

Table 2. Effects of L. plantarumU40 on Rumen Fermentation Product from 8 Hours Incubation

\begin{tabular}{lccc}
\hline \multirow{2}{*}{ Parameters } & \multicolumn{3}{c}{ Treatments } \\
\cline { 2 - 4 } $\mathrm{pH}$ & Control & L. plantarumU40 & L. plantarum U40 + glucose \\
\hline Total VFA (mM) & $6.85^{\mathrm{b}}$ & $6.84^{\mathrm{b}}$ & $6.30^{\mathrm{a}}$ \\
Acetic acid (\%) & 63.95 & 70.42 & 60.46 \\
Propionic acid (\%) & $45.11^{\mathrm{ab}}$ & $47.71^{\mathrm{b}}$ & $41.40^{\mathrm{a}}$ \\
Butyric acid (\%) & $24.65^{\mathrm{a}}$ & $23.18^{\mathrm{a}}$ & $27.91^{\mathrm{b}}$ \\
Isobutyric acid (\%) & 11.91 & 11.99 & 12.77 \\
Valeric acid (\%) & 9.89 & 8.66 & 10.04 \\
Isovaleric acid (\%) & 2.91 & 2.82 & 2.54 \\
$\mathrm{~A} /$ P ratio & 5.56 & 5.64 & 5.37 \\
$\mathrm{NH}_{3}(\mathrm{mM})$ & $1.85^{\mathrm{b}}$ & $2.07^{\mathrm{c}}$ & $1.49^{\mathrm{a}}$ \\
\hline
\end{tabular}

Different superscripts within the same row indicate significantly different at $\mathrm{P}<0.05$.

VFA=Volatile Fatty Acids; A/P ratio $=$ Acetic acid/propionic acid ratio

inoculation of L. plantarum U40 without glucose addition $(47.71 \%)$. Control treatment did not significantly different compared with both inoculated treatments. Glucose addition provides inoculated L. plantarum U40 with nutrition, to ensure they can survived and interact with rumen microbes to shifts rumen fermentation. Without glucose, L. plantarum U40 can survived in rumen fluid, but they could not produce lactic acid as much as with glucose addition. This hypothesis 
was in line with value of rumen $\mathrm{pH}$ with and without glucose addition. This suggests that shifts of rumen fermentation by inoculation of $L$. plantarum U40 influenced by their survival and activity in rumen fluid.

Propionic acid production was significantly increased $(\mathrm{P}<0.05)$ by inoculation of $L$. plantarum U40 with glucose addition (27.91\%), compared with control (24.66\%). But inoculation of $L$. plantarum U40 without glucose addition did not affect propionic acid production significantly. Increased propionic acid could be caused by increased lactic acid produced by $L$. plantarum U40. Higher lactic acid in rumen fluid trigger lactic acid utilizer growth. Some lactic acid utilizer such as Megasphaera elsdenii and Propionibacterium will consume lactic acid, leading to increased production of propionic acid (Seo et al., 2010; Luo et al., 2017). Increased propionic acid after inoculation of L. plantarum also reported by Weinberg et al. (2003). Butyric and valeric acid were not affected by $L$. plantarum U40 inoculation. The changes in VFA composition showed one beneficial role of $L$. plantarum $\mathrm{U} 40$ as probiotic for ruminant. But other research also reported that inoculation of $L$. plantarum or other $\mathrm{LAB}$ did not affect rumen fermentation, more specific on VFA composition. This inconsistency can be concluded that the effect of L. plantarum inoculation as probiotic on rumen fermentation depends on the type of strains, dose and substrate utilization (Jiao et al., 2017).

Concentration of $\mathrm{NH}_{3}$ in the rumen fluid increased significantly $(\mathrm{P}<0.05)$ by inoculation of L. plantarum $\mathrm{U} 40$ without glucose addition (23.06 $\mathrm{mM})$, compared both with control (20.01) and $L$. plantarum U40 with glucose addition (19.53 mM). Rumen $\mathrm{NH}_{3}$ is needed for microbial protein synthesis. Deficiency of $\mathrm{NH}_{3}$ will inhibit microbial synthesis, while high concentration of $\mathrm{NH}_{3}$ also inhibit microbial utilization of this compound (Hristov et al., 2011). Rumen $\mathrm{NH}_{3}$ was products from protein degradation. This in vitro study did not add any protein source, therefore $\mathrm{NH}_{3}$ in this case was resulted from rumen microbial cell. Lower $\mathrm{NH}_{3}$ in treatment with glucose addition strengthen hypothesis that high $\mathrm{NH}_{3}$ after inoculation of L. plantarumU40 without glucose addition was resulted from digestion of death rumen microbes caused by lack of nutrient source.

Glucose addition resulted in different $\mathrm{A} / \mathrm{P}$ (acetic acid/propionic acid ratio), due to different acetic and propionic acid production from $L$. plantarum $\mathrm{U} 40$ inoculation. Compared with control (1.85), L. plantarum $\mathrm{U} 40$ without glucose addition significantly increased $\mathrm{A} / \mathrm{P}$ ratio (2.07), while glucose addition decreased $\mathrm{A} / \mathrm{P}$ ratio (1.49). Other research also reported decreased $\mathrm{A} / \mathrm{P}$ ratio by inoculation of several different LAB on in vitro fermentation system (Jiao et al., 2017). Decreased $\mathrm{A} / \mathrm{P}$ ratio indicated higher efficiency of rumen fermentation which correlated with improved growth efficiency (Kenney et al., 2015). Increased propionic acid proportion lead to decreased methane production in the rumen because of hydrogen was used for propionic acid production. Decreased of methane by LAB inoculation reported by previous studies, with highest reduction up to $60 \%$ in cumulative methane (O'Brien et al., 2013; Chang et al., 2014; Soriano et al., 2014; Astuti et al., 2018). Methane produced by ruminant represents an energy loss for the host animal of $2-12 \%$ of dietary energy (Moss et al., 2000), therefore decreased methane production will increase energy supply for the animal, followed by increased productivity. Other researchers also focused on lowering methane production because of its contribution to global warming (Martin et al., 2010).

\section{CONCLUSION}

Lactobacillus plantarum U40 can survive in rumen fluid. It changes rumen fermentation by increasing propionic acid proportion when glucose is added as carbon source. Therefore Lactobacillus plantarum U40 can be a potential probiotic for ruminant.

\section{ACKNOWLEDGMENTS}

The authors wish to acknowledge the financial support received from "DIPA UnggulanLIPI (2015-2017) Food Security and Drug's Discovery" of the Research Center for Biotechnology-Indonesian Institute of Sciences (LIPI) and LPDP (Lembaga Pengelola Dana Pendidikan) scholarship.

\section{REFERENCES}

Astuti, W.D., K.G. Wiryawan, E. Wina, Y. Widyastuti, S. Suharti and R. Ridwan. 2018. Effects of selected Lactobacillus plantarum as probiotic on in vitro ruminal fermentation 
and microbial population. Pakistan J. Nutr. 17(3):131-139

Cappucino, J.G. and N. Sherman. 2001. Microbiology: A laboratory manual. $6^{\text {th }} \mathrm{Ed}$. State University of New York, Rockland Community College. New York

Chang, K. and S.S. Lee. 2014. Effect of Lactobacillus mucosae on in vitro rumen fermentation characteristic of dried brewers grain, methane production and bacterial diversity. Asian-Aust. J. Anim. Sci. 11:1562-1570.

Cheng, G., H. Hao, S. Xie, X. Wang, M. Dai, L. Huang and Z. Yuan. 2014. Antibiotic alternatives: the substitution of antibiotics in animal husbandry? Frontiers in Microbiol. 5:217

Ellis, J.L., A. Bannink, I.K. Hindrichsen, R.D. Kinley, W.F. Pellikaan, N. Milora and J. Dijkstra. 2016. The effect of lactic acid bacteria included as probiotic or silage inoculant on in vitro rumen digestibility, total gas and methane production. Anim. Feed Sci. Technol. 211:61-74

Food Agricultural Organization (FAO)/World Health Organization (WHO). 2001. Evaluation of health and nutritional properties of probiotics in food including powder milk with live lactic acid bacteria. Expert consultation report. Cordoba, Argentina, Food and Agriculture Organization of United Nations and World Health Organization.

Food Agricultural Organization (FAO)/World Health Organization (WHO). 2002. Report of a joint FAO/WHO Expert Consultation on Guidelines for the Evaluation of Probiotics in Food. World Health Organization and Food and Agriculture Organization of the United Stations, London Ontario, Canada.

General Laboratory Procedures. 1966. Report of Dairy Science. Madison, USA, University of Wisconsin.

Grilli, D.J., K. Fliegerova, J. Kopecny, S.P. Lama, V. Egea, N. Sohaefer, C. Pereyra, M.S. Ruiz, M.A. Sosa, G.N. Arenas and J. Mrazek. 2016. Analysis of the rumen bacterial diversity of goats during shift from forage to concentrate diet. Anaerobe 24:1726

Hristov, A.N., M. Hanigan, A. Cole, R. Todd, T.A. McAllister, P.M. Ndegwa and A. Rotz. 2011. Review: Ammonia emissions from dairy farms and beef feedlots. Can. J. Anim. Sci. 91:1-35

Jiao, P.X., F.Z.Liu, K.A.Beauchemin andW.Z.Yang. 2017. Impact of strain and dose of lactic acid bacteria on in vitro ruminal fermentation with varying media $\mathrm{pH}$ levels and feed substrates. Anim. Feed Sci. Technol., 224:1-13.1

Kenney, N.M., E.S. Vanzant, D.L.Harmon and K.R.McLeod. 2015. Direct-fed microbials containing lactate-producing bacteria influence ruminal fermentation but not lactate utilization in steers fed a highconcentrate diet. J. Anim. Sci.93:2336-2348

Klocke, M., K. Mundt, C. Idler, J. McEniry, P. O'Kiely and S. Barth. 2006. Monitoring Lactobacillus plantarum in grass silages with the aid of 16S rDNA-based quantitative real-time PCR assays. System. Appl. Microbiol. 29:49-58

Krause, K.M. andG.R. Oetzel. 2006. Understanding and preventing ruminal acidosis in dairy herds: a review. Anim Feed Sci. Technol. 126:215-236

Luo, J., C.S. Ranadheera, S. King, C. Evans and S. Baines. 2017. In vitro investigation of the effect of dairy propionibacteria on rumen $\mathrm{pH}$, lactic acid and volatile fatty acids. J. Integrative Agric. 16(7):1566-1575

Martin, C., D.P. Morgavi and M. Doreau. 2010. Methane mitigation in ruminants: from microbe tothe farm scale. Animal4:351-365

McAllister, T., K.A.Beauchemin, A.Y.Alazzeh, J. Baah, R.M.Teather and K.Stanford. 2011. The use of direct fed microbials to mitigate pathogens and enhance production in cattle. Can. J. Anim. Sci 91:193-211

Moss, A.R., J.P. Jouany and J. Newbold. 2000. Methane production by ruminants: Its contribution to global warming. Annal. Zootech. 49:231-253

O’Brien, M., T. Hashimoto, A. Senda, T. Nishida and J. Takahashi. 2013. The impact of Lactobacillus plantarum TUA1490L supernatant on in vitro rumen methanogenesis and fermentation. Anaerobe 22:137-140

Ohashi Y and K. Ushida. 2009. Health-beneficial effects of probiotic: its mode of action. Anim. Sci. J. 80:361-371

Ridwan, R., I. Rusmana, Y. Widyastuti, K.G. Wiryawan, B. Prasetya, M. Sakamoto and M. Ohkuma. 2015. Fermentation characteristics and microbial diversity of 
tropical grass-legumes silages. Asian-Aust. J. Anim. Sci. 28(4):511-518

Ridwan, R., W. A. Bungsu, W. D. Astuti, Rohmatussolihat, N.F. Sari, R. Fidriyanto, A. Jayanegara, I.W. and Y.Widyastuti. 2018. The use of lactic acid bacteria as ruminant probiotic candidates based on in vitro rumen fermentation characteristics. Buletin Peternakan 42(1): 31-36

Rodriguez-Palacios, A., H.R. Staempfli, T. Duffield and J.S. Weese. 2009. Isolation of bovine intestinal Lactobacillus plantarum and Pediococcus acidilactici with inhibitory activity against Escherichia coli $\mathrm{O} 157$ and F5. J. Appl. Microbiol. 106:393-401

Seo, J.K., S.W. Kim, M.H. Kim, S.D. Upadhaya, D.K. Kam and J.K. Ha. 2010. Direct-fed microbials for ruminant animals. AsianAust. J. Anim. Sci., 23:1657-1667

Singh, K.M., P.R. Pandya, A.K. Tripathi, G.R. Patel, S. Parnerkar, R.K. Kothari and C.G. Joshi. 2014. Study of rumen metagenome community using qPCR under different diets. Meta Gene 2:191-199

Smetanková, J., Z. Hladíková, F. Valach, M. Zimanová, Z. Kohajdová, G. Greif and M. Greifová. 2012. Influence of aerobic and anaerobic conditions on the growth and metabolism of selected strains of Lactobacillus plantarum. Acta Chimica
Slovaca 5(2):204-210

Soriano, A.P., L.L. Mamuad, S.H. Kim, Y.J. Choi, C.D. Jeong, G.S. Bae, M.B. Chang and S.S. Lee. 2014. Effect of Lactobacillus mucosae on in vitro rumen fermentation characteristic of dried brewers grain, methane production and bacterial diversity. Asian-Aust. J. Anim. Sci. 11:1562-1570

Theodorou, M.K., B.A.Williams,M.S.Dhanoa, A.B.McAllan and J. France. 1994. A simple gas production method using a pressure transducer to determine the fermentation kinetic of ruminant feeds. Anim. Feed Sci. Technol.48:185-197

Wanapat, M. and A. Cherdthong. 2009. Use of real-time PCR technique in studying rumen cellulolytic bacteria population as affected by level of roughage in swamp buffalo. Curr. Microbiol. 58:294-299

Weinberg Z.G., R. Muck and P.J. Weimer. 2003. The survival of silage inoculant lactic acid bacteria in rumen fluid. J. Appl. Microbiol. 94:1066-1071

Weinberg Z.G., R. Muck, P.J. Weimer,Y. Chen and M. Gamburg. 2004. Lactic acid bacteria used in inoculants for silage as probiotics for ruminants. Appl. Biochem. Biotechnol. 118:1-9

Yirga, H. 2015. The use of probiotics in animal nutrition. J. Prob. Health 3:132 